\title{
Stabilisasi/Solidifikasi Tailing Tambang Emas Rakyat Kulon Progo Menggunakan Semen Portland dan Tanah Tras
}

\author{
Thaniya Triagustine Kalimantoro dan Yulinah Trihadiningrum \\ Jurusan Teknik Lingkungan, Fakultas Teknik Sipil dan Perencanaan, Institut Teknologi Sepuluh Nopember (ITS) \\ Jl. Arief Rahman Hakim, Surabaya 60111 Indonesia \\ e-mail: yulinah_t@enviro.its.ac.id
}

\begin{abstract}
Abstrak-Merkuri digunakan dalam proses amalgamasi untuk mengikat emas. Namun, penggunaan merkuri pada tambang emas rakyat Kulon Progo, DI Yogyakarta mengakibatkan pencemaran tanah dan badan air di sekitar lokasi tambang. Tailing mengandung merkuri yang dihasilkan dari pengolahan emas ditampung dalam kolam dan seringkali dibiarkan hingga penuh dan meluap ke area sekitarnya. Tailing tergolong limbah B3 kategori 2 menurut Lampiran I PP No. 101 Tahun 2014 tentang Pengelolaan Limbah Bahan Berbahaya dan Beracun. Konsentrasi merkuri dalam tailing mencapai $302,31 \mathrm{mg} / \mathrm{kg}$. Upaya remediasi melalui stabilisasi/solidifikasi (S/S) dilakukan untuk mencegah penyebaran merkuri. Semen Portland dan tanah tras digunakan sebagai binder dalam proses $S / S$ ini. Komposisi terbaik antara semen dan tanah tras serta komposisi terbaik antara binder dan tailing ditentukan dalam penelitian ini. Penentuan didasarkan dari hasil uji kuat tekan dan uji TCLP terhadap benda uji. Benda uji berbentuk kubus dengan ukuran tiap sisi $5 \mathrm{~cm}$. Baku mutu uji kuat tekan menurut Kep. Bapedal No. KEP-03/BAPEDAL/09/1995 adalah 10 ton/ $\mathrm{m}^{2}$. Baku mutu TCLP menurut Lampiran IV PP No 101 Tahun 2014 yaitu 0,05 mg/L. Variasi komposisi semen dan tanah tras adalah 100:0 ; $90: 10 ; 80: 20 ; 30: 70 ; 60: 40 ; 50: 50 ; 40: 60 ; 30: 70 ; 20: 80$ dan 10:90. Komposisi terbaik ditetapkan pada komposisi 40:60 dengan nilai kuat tekan sebesar $260 \mathrm{~kg} / \mathrm{cm}^{2}$. Variasi komposisi binder dan tailing yaitu 50:50; 40:60 ; 30:70 ; 20:80 dan 10:90. Komposisi terbaik ditetapkan pada komposisi 50:50 dengan nilai kuat tekan 92,4 kg/cm² dan nilai TCLP kurang dari 0,21 mg/L.
\end{abstract}

Kata Kunci-Merkuri, semen Portland, S/S, tailing, tanah tras.

\section{PENDAHULUAN}

$\mathrm{M}$ ERKURI merupakan logam cair berwarna putih keperakan pada suhu ruang dengan titik didih dan titik beku sebesar $357^{\circ} \mathrm{C}$ dan $-38,9^{\circ} \mathrm{C}$. Berat jenis merkuri adalah $13,55 \mathrm{gram} / \mathrm{cm}^{3}$ sehingga tergolong sebagai logam berat karena memiliki berat jenis lebih dari $5 \mathrm{gram} / \mathrm{cm}^{3}$ [1]. Merkuri di alam dapat dijumpai dalam tiga bentuk, yaitu merkuri elemental $\left(\mathrm{Hg}^{0}\right)$, merkuri inorganic $\left(\mathrm{Hg}^{+}\right.$dan $\left.\mathrm{Hg}^{2+}\right)$ dan merkuri organik (metil merkuri dan etil merkuri) [2]. Emisi merkuri terbesar di Indonesia berasal dari kegiatan penambangan emas skala kecil yang dikenal dengan istilah Pertambangan Tanpa Izin (PETI) [3,4]. Salah satu usaha PETI yang masih beroperasi yaitu tambang emas rakyat di Dusun Sangon, Kulon Progo, DI Yogyakarta. Tailing yang dihasilkan dari kegiatan pengolahan emas mengandung merkuri dengan konsentrasi $302,31 \mathrm{mg} / \mathrm{kg}$. Tailing ditampung pada kolam penampungan yang seringkali dibiarkan hingga penuh dan meluap, sehingga mencemari tanah serta badan air di sekitar lokasi tambang. Hal itu memperbesar peluang pemaparan merkuri terhadap tubuh yang berdampak buruk bagi kesehatan. Dampak buruk yang ditimbulkan oleh merkuri yaitu gangguan sistem saraf, sistem pencernaan, sistem kekebalan tubuh hingga kerusakan paru-paru dan kematian.

Pengelolaan terhadap tailing yang tergolong sebagai limbah B3 kategori 2 menurut Tabel 4 Lampiran I PP No. 101 Tahun 2014 melalui teknik S/S perlu dilakukan untuk mencegah pencemaran merkuri ke area yang lebih luas. Stabilisasi merupakan proses yang melibatkan reaksi kimia untuk menurunkan tingkat mobilitas atau pelindian suatu kontaminan [5,6]. Solidifikasi diartikan sebagai proses penambahan bahan aditif tertentu untuk mengubah kontaminan ke dalam fase yang lebih padat sehingga memperkecil luas permukaannya [5]. S/S digunakan sebagai alternatif pengolahan karena produk $\mathrm{S} / \mathrm{S}$ memiliki stabilitas fisik dan kimia jangka panjang yang baik. Hasil $\mathrm{S} / \mathrm{S}$ juga resisten terhadap proses biodegradasi serta lebih kedap air [7]. Keberhasilan proses $\mathrm{S} / \mathrm{S}$ sangat bergantung pada keefektifan bahan aditif atau binder yang digunakan dalam mengikat kontaminan baik secara fisik maupun kimia.

Semen Portland banyak digunakan sebagai binder karena mengandung silikat $\left(\mathrm{SiO}_{2}\right)$, aluminat $\left(\mathrm{Al}_{2} \mathrm{O}_{3}\right)$ serta kapur $(\mathrm{CaO})$ yang memberikan sifat keras pada semen ketika bereaksi dengan air. Reaksi hidrasi pada semen akan menghasilkan senyawa kalsium silikat hidrat dan kalsium aluminat hidrat yang berperan penting dalam pengerasan semen [6]. Penggunaan semen dalam aplikasi S/S perlu dibatasi karena biaya produksi semen yang mahal. Produksi semen juga menghasilkan emisi gas rumah kaca yang cukup besar [8]. Pembatasan penggunaan semen dilakukan dengan menggunakan bahan pengganti semen yaitu tanah tras.

Tanah tras merupakan tanah hasil pelapukan batuan dari aktivitas gunung berapi yang mengandung silikat dalam jumlah tinggi. Butiran silikat yang sangat halus mengisi ruang antar partikel dalam beton sehingga dapat meningkatkan nilai kuat tekan beton. Silikat ketika bereaksi dengan kapur dan air menghasilkan kalsium silikat hidrat yang dapat mengeras dan bersifat kedap air [9]. Aluminat yang juga terkandung dalam tanah tras dapat mempercepat reaksi hidrasi. Tanah tras juga mudah diperoleh di sekitar lokasi tambang sebab Kulon Progo 
merupakan kabupaten penghasil bahan galian mineral tanah tras [10].

Mengacu pada latar belakang di atas, maka dilakukan pengujian kualitas produk $\mathrm{S} / \mathrm{S}$ pada berbagai variasi perbandingan semen dan tanah tras untuk menentukan komposisi terbaik dari campuran keduanya. Penentuan komposisi terbaik antara binder dan tailing juga perlu dilakukan sebagai informasi penting dalam pengaplikasian teknik S/S yang lebih murah dan efektif. Kualitas produk S/S diuji melalui uji kuat tekan dan uji TCLP. Baku mutu uji kuat tekan menurut Kep. Bapedal No. KEP-03/BAPEDAL/09/1995 adalah 10 ton $/ \mathrm{m}^{2}$. Baku mutu TCLP menurut Lampiran IV PP No 101 Tahun 2014 yaitu $0,05 \mathrm{mg} / \mathrm{L}$.

\section{METODE PENELITIAN}

\section{A. Pengambilan Sampel Tailing}

Pengambilan tailing dilakukan secara acak sederhana pada 5 kolam penampungan di lokasi tambang emas rakyat Dusun Sangon, Kulon Progo, DI Yogyakarta seperti dapat dilihat pada Gambar 1. Kedalaman pengambilan yaitu pada titik 10 $\mathrm{cm}$ dari permukaan sedimen tailing. Sedimen tailing $1,5 \mathrm{~kg}$ diambil dari tiap titik sampel dan dikompositkan. Sampel komposit tailing disimpan dalam botol HDPE bermulut lebar untuk diuji konsentrasi merkurinya. Sampel disimpan dalam

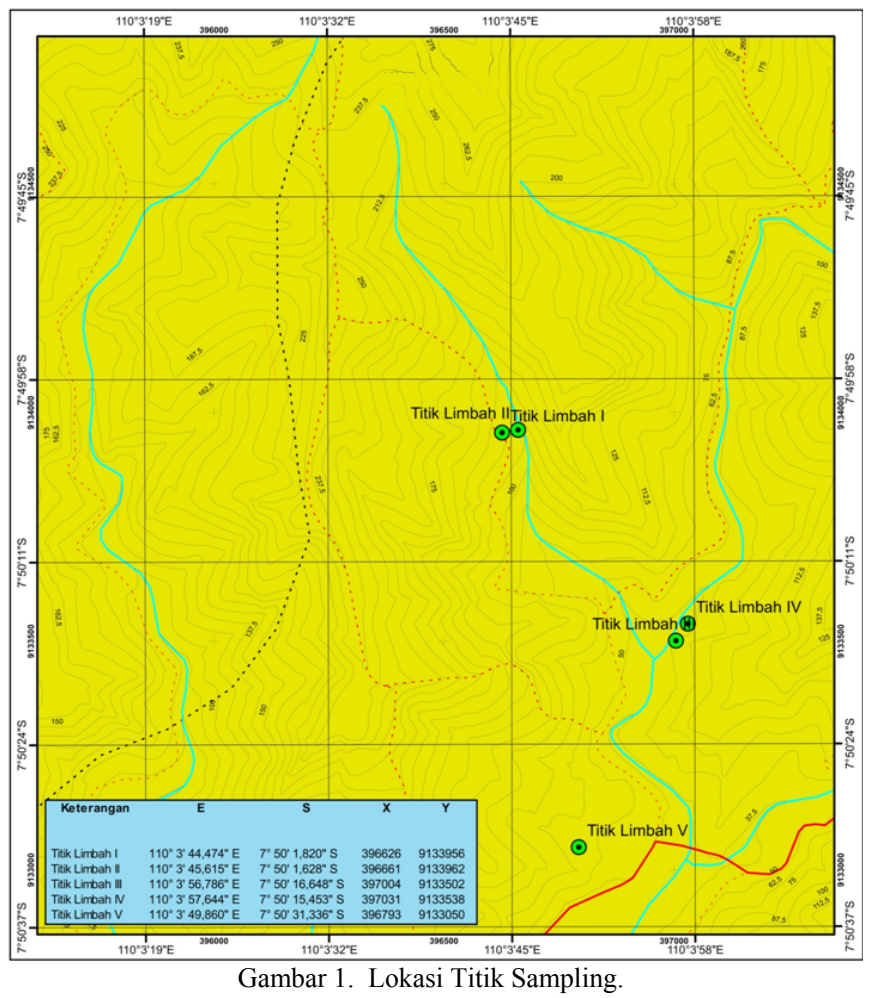

cool box berisi es untuk menghindari penguapan merkuri.

\section{B. Uji Kadar Merkuri dan Karaketrisasi Tailing}

Uji kadar merkuri dilakukan di LPPT UGM Yogyakarta menggunakan Mercury Analyzer. Karakterisasi tailing meliputi pengukuran kadar air dan $\mathrm{pH}$. Pengujian kadar air dilakukan dengan metode gravimetri, sedangkan $\mathrm{pH}$ diukur dengan $\mathrm{pH}$-meter. Persiapan sampel tailing untuk pembuatan benda uji dilakukan dengan mengeringkan sampel pada suhu $105^{\circ} \mathrm{C}$ selama 2,5 jam. Tailing kemudian dihaluskan menggunakan alat bond ball mild dan diayak menggunakan ayakan $300 \mu \mathrm{m}$.

\section{Pembuatan Benda Uji}

Pembuatan benda uji menggunakan specimen mould berbentuk kubus dengan ukuran tiap sisi $5 \mathrm{~cm}$. Pembuatan dilakukan dalam 2 tahap. Pada penelitian tahap I dibuat 10 benda uji dengan variasi komposisi semen dan tanah tras yaitu 100:0 ; 90:10 ; 80:20 ; 30:70 ; 60:40 ; 50:50 ; 40:60 ; 30:70 ; 20:80 dan 10:90. Penelitian tahap II dibuat 5 benda uji dengan variasi komposisi binder dan tailing sebesar 50:50 ; 40:60 ; $30: 70 ; 20: 80$ dan 10:90. Tata cara pengadukan, pembuatan benda uji, pemadatan dan perawatan benda uji mengacu pada SNI 2493:2011.

Penentuan kebutuhan air untuk pembuatan benda uji dilakukan melalui uji konsistensi normal menggunakan alat vicat. Kondisi konsisten normal dimana kebutuhan air telah tercukupi tercapai ketika jarum vicat menunjukkan penurunan sebesar $10 \mathrm{~mm}$ dalam waktu 30 detik. Semen, tanah tras dan air dengan volume sesuai hasil konsistensi normal diaduk hingga homogen dan dicetak menggunakan specimen mould.

\section{Perawatan Benda Uji}

Perawatan benda uji dilakukan dengan teknik moisture curing selama 28 hari. Benda uji diletakkan pada bak tertutup dengan wadah berisi air di dalamnya seperti pada Gambar 2. Teknik ini memungkinkan kelembaban udara tetap terjaga

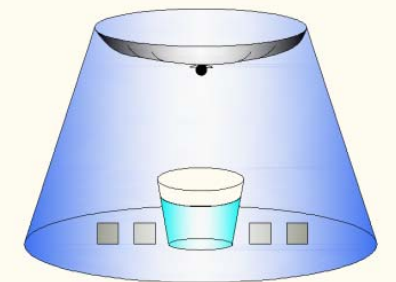

Gambar 2. Prosedur Moisture Curing.

sehingga dapat menghindari retak pada benda uji selama masa curing akibat kurangnya ketersediaan air untuk proses hidrasi.

\section{E. Uji Kuat Tekan}

Pelaksanaan uji kuat tekan mengacu pada ASTM C109 tentang Compressive Strength of Hydraulic Cement Mortars. Uji kuat tekan dilakukan untuk mengetahui besarnya beban maksimal yang dapat diterima oleh benda uji. Baku mutu kuat tekan adalah 10 ton $/ \mathrm{m}^{2}$ atau setara dengan $1 \mathrm{~kg} / \mathrm{cm}^{2}$.

\section{F. Uji TCLP}

Pelaksanaan uji TCLP mengacu pada US EPA Standard Method 1311. Merkuri dalam benda uji dilarutkan menggunakan larutan ekstraksi yang mengandung asam asetat glasial dengan $\mathrm{pH}$ rendah. Proses rotasi-agitasi dalam uji ini dilakukan dengan rotary agitator pada kecepatan $30 \pm 2 \mathrm{rpm}$ selama $18 \pm 2 \mathrm{jam}$. Larutan sampel kemudian diendapkan dan diambil filtratnya. Filtrat disimpan dalam botol kaca berwarna coklat dan diuji konsentrasi merkurinya. Uji kadar merkuri 
dilakukan di Laboratorium CDEA Universitas Surabaya menggunakan ICP-AES.

\section{G. Analisis Data dan Kesimpulan}

Berdasarkan hasil uji kuat tekan terhadap benda uji tahap I ditentukan komposisi terbaik antara semen dan tanah tras. Analisis data yang dilakukan meliputi pembahasan hubungan antara kebutuhan air dan nilai kuat tekan dengan persen semen dan tanah tras. Berdasarkan hasil uji kuat tekan dan uji TCLP terhadap benda uji tahap II ditentukan komposisi terbaik antara binder dan tailing. Analisis meliputi pembahasan hubungan antara kebutuhan air, nilai kuat tekan dan hasil uji TCLP dengan persen binder dan tailing tiap benda uji.

\section{HASIL DAN DISKUSI}

\section{A. Pengambilan dan Karakterisasi Sampel Tailing}

Kegiatan sampling dilaksanakan pada bulan Oktober tahun 2015. Koordinat kelima titik sampling dapat dilihat pada

Tabel 1.

Koordinat Titik Sampling

\begin{tabular}{|c|c|c|}
\hline \multirow{2}{*}{ Titik Sampling } & \multicolumn{2}{|c|}{ Titik Koordinat } \\
\hline & Bujur & Lintang \\
\hline Titik Sampling I & $110^{\circ} 3$ ' 44,474" E & $7^{\circ} 50^{\prime} 1,820^{\prime \prime} \mathrm{S}$ \\
\hline Titik Sampling II & $110^{\circ} 3,45,615^{\prime \prime} \mathrm{E}$ & $7^{\circ} 50^{\prime} 1,628^{\prime \prime} \mathrm{S}$ \\
\hline Titik Sampling III & $110^{\circ} 3 ' 56,786^{\prime \prime} \mathrm{E}$ & $7^{\circ} 50,16,648 ” S$ \\
\hline Titik Sampling IV & $110^{\circ} 3$ '57,644” E & $7^{\circ} 50^{\prime} 15,453 ” \mathrm{~S}$ \\
\hline Titik Sampling V & $110^{\circ} 3$ ' 49,860" E & $7^{\circ} 50^{\prime} 31,336 ” \mathrm{~S}$ \\
\hline
\end{tabular}

Tabel 1. Karakteristik fisik tailing sesaat setelah kegiatan sampling yaitu berwarna abu-abu kecoklatan dengan butiran relatif halus dan seragam.

Hasil pengujian $\mathrm{pH}$ menunjukkan bahwa tailing tergolong basa dengan $\mathrm{pH}$ sebesar 8,33. Hal ini dikarenakan dalam proses pengolahan emas dilakukan penambahan semen untuk mengikat zat pengotor selain emas. Kalsium, silikat dan aluminat dalam semen bereaksi dengan air sehingga menghasilkan kalsium hidroksida $\mathrm{Ca}(\mathrm{OH})_{2}$ yang merupakan basa kuat [11].

Tailing memiliki kadar air yang tergolong cukup tinggi yaitu sebesar $7,85 \%$ sehingga perlu dilakukan pengeringan terlebih dahulu. Tingginya kadar air dikarenakan tailing diambil dari sedimen di bagian bawah kolam yang juga masih bercampur dengan air sisa proses pengolahan emas. Total konsentrasi (TK) merkuri pada tailing berdasarkan uji kadar merkuri yaitu sebesar $302,31 \mathrm{mg} / \mathrm{kg}$.

\section{B. Uji Konsistensi Normal Benda Uji Tahap I}

Hasil uji konsistensi normal tahap I sesuai Tabel 2 menunjukkan bahwa terjadi peningkatan kebutuhan air seiring dengan peningkatan persen tanah tras yang digunakan. Hal ini dikarenakan tanah tras mengandung silikat reaktif yang dapat melakukan kemisorpsi dengan air membentuk gugus $\mathrm{Si}-\mathrm{OH}$ [12]. Kandungan silikat dalam tanah tras mencapai 46\% [9]. Tingginya kandungan silikat serta reaktifitasnya terhadap air
Tabel 2 .

Kebutuhan Air Benda Uji Tahap I

\begin{tabular}{cc}
\hline \hline Semen : Tanah Tras & Volume Air $(\mathrm{mL})$ \\
\hline $100: 0$ & 78 \\
$90: 10$ & 75 \\
$80: 20$ & 75 \\
$70: 30$ & 77 \\
$60: 40$ & 76 \\
$50: 50$ & 78 \\
$40: 60$ & 78 \\
$30: 70$ & 79 \\
$20: 80$ & 82 \\
$10: 90$ & 84 \\
\hline \hline
\end{tabular}

memberikan dampak yang signifikan terhadap kebutuhan air masing-masing benda uji.

\section{Uji Kuat Tekan Benda Uji Tahap I}

Nilai kuat tekan yang dihasilkan masing-masing benda uji pada penelitian tahap I dapat dilihat pada Tabel 3 . Berdasarkan grafik hubungan antara nilai kuat tekan dengan persen semen dan tanah tras yang digunakan seperti pada Grafik 1, peningkatan persen semen mengakibatkan peningkatan nilai kuat tekan benda uji. Semakin tinggi persen semen, maka senyawa hidrat yang terbentuk melalui reaksi hidrasi semen juga semakin banyak. Senyawa hidrat berupa kalsium silikat hidrat dan kalsium aluminat hidrat yang memberikan sifat keras pada campuran semen terbentuk melalui reaksi hidrasi berikut [6] :

$2\left(3 \mathrm{CaO} . \mathrm{SiO}_{2}\right)+6 \mathrm{H}_{2} \mathrm{O} \rightarrow 3 \mathrm{CaO} .2 \mathrm{SiO}_{2} \cdot 3 \mathrm{H}_{2} \mathrm{O}+3 \mathrm{Ca}(\mathrm{OH})_{2}$

$$
2\left(2 \mathrm{CaO}^{2} \mathrm{SiO}_{2}\right)+4 \mathrm{H}_{2} \mathrm{O} \rightarrow 3 \mathrm{CaO} \cdot 2 \mathrm{SiO}_{2} \cdot 3 \mathrm{H}_{2} \mathrm{O}+\mathrm{Ca}(\mathrm{OH})_{2}
$$$$
\text { Di-kalsium silikat Air Kalsium silikat hidrat Kalsium hidroksida }
$$

$3 \mathrm{CaO} . \mathrm{Al}_{2} \mathrm{O}_{3}+12 \mathrm{H}_{2} \mathrm{O}+\mathrm{Ca}(\mathrm{OH})_{2} \rightarrow 3 \mathrm{CaO} \cdot \mathrm{Al}_{2} \mathrm{O}_{3} \cdot \mathrm{Ca}(\mathrm{OH})_{2} \cdot 12 \mathrm{H}_{2} \mathrm{O}$

Tri-kalsium aluminat Air Kalsium hidroksida Tetrakalsium aluminat hidrat

Reaksi hidrasi antara di-kalsium silikat dan tri-kalsium silikat dengan air menghasilkan kalsium silikat hidrat dan kalsium hidroksida. Kalsium hidroksida yang terbentuk selanjutnya akan digunakan dalam reaksi hidrasi antara trikalsium aluminat dengan air yang menghasilkan tetrakalsium aluminat hidrat. Senyawa-senyawa hidrat tersebut merupakan faktor utama yang menentukan kekuatan benda uji. Senyawa hidrat akan membentuk kristal halus yang menambah kekuatan dan kepadatan benda uji.

Tabel 3.

Nilai Kuat Tekan Benda Uji Tahap I

\begin{tabular}{cc}
\hline \hline Semen $:$ Tras & Nilai Kuat Tekan $(\mathrm{kg} / \mathrm{cm} 2)$ \\
\hline $10: 90$ & 96 \\
$20: 80$ & 171 \\
$30: 70$ & 206 \\
$40: 60$ & 260 \\
$50: 50$ & 262 \\
$60: 40$ & 315 \\
$70: 30$ & 403 \\
$80: 20$ & 410 \\
$90: 10$ & 391 \\
$100: 0$ & 487 \\
\hline \hline
\end{tabular}


Kalsium silikat hidrat juga dihasilkan melalui reaksi pozzolanic pada tanah tras berikut ini [11] :

$$
\underset{\text { Silikat }}{\mathrm{SiO}_{2}}+\underset{\text { Kalsium hidroksida }}{\mathrm{Ca}(\mathrm{OH})_{2}} \rightarrow \underset{\text { Kalsium silikat hidrat }}{\mathrm{CaO} \cdot \mathrm{SiO}_{2} \cdot \mathrm{H}_{2} \mathrm{O}}
$$

Tanah tras dalam keadaan halus dapat bereaksi dengan kapur bebas dan air membentuk suatu massa padat yang tidak larut dalam air [13]. Hal ini dikarenakan tanah tras mengandung komponen silikat yang akan menghasilkan reaksi pozzolanic ketika berekasi dengan air dan kapur [14]. Terbentuknya massa padat yang tidak larut dalam air tersebut

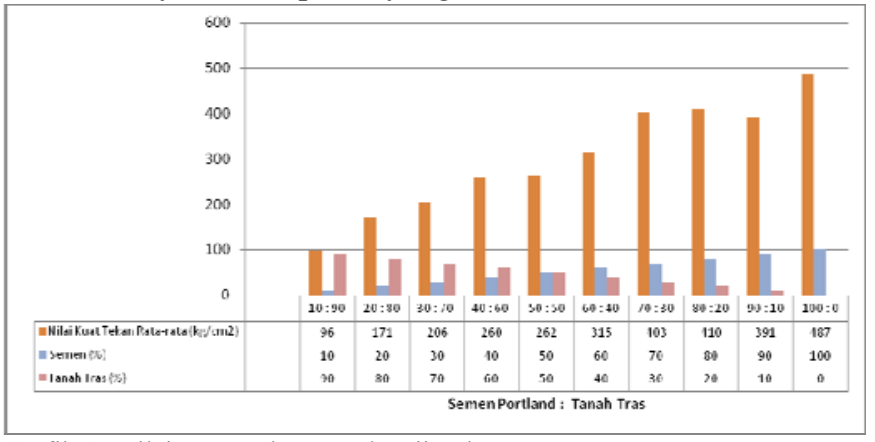

Grafik 1. Nilai Kuat Tekan Benda Uji Tahap I.

terjadi karena adanya kalsium silikat hidrat yang memberikan sifat hidrolis pada tanah tras.

Namun sebagai pozzolan, tanah tras tidak dapat memiliki sifat semen tanpa adanya kalsium hidroksida yang dihasilkan dari reaksi hidrasi semen. Dengan demikian, keberlangsungan reaksi pozzolanic sangat bergantung pada ketersediaan kapur bebas ataupun kalsium hidroksida pada semen. Bahkan kadar kapur yang terlalu rendah tidak dapat menghasilkan proses hidrasi atau reaksi pozzolanic sama sekali [15]. Peningkatan persen tanah tras tanpa diimbangi dengan peningkatan persen semen tidak menghasilkan peningkatan nilai kuat tekan sebab reaksi hidrasi dan pozzolanic tidak berlangsung sempurna.

Selain itu, semakin tinggi persen tanah tras maka silika yang tersedia juga semakin tinggi. Kandungan silika yang berlebihan dapat menurunkan nilai kuat tekan akibat timbulnya reaksi alkali silika. Reaksi alkali silika merupakan reaksi antara silika aktif pada tanah tras dengan alkali silika yang terdapat pada semen. Reaksi tersebut membentuk gel alkali yang dikelilingi oleh pasta semen dan mengakibatkan pemuaian pada benda uji. Pemuaian yang terjadi akan berakibat pada retak atau pecahnya pasta semen sehingga menurunkan nilai kuat tekan benda uji [13]. Hal tersebut sesuai dengan hasil uji kuat tekan pada benda uji tahap I yang menunjukkan penurunan nilai kuat tekan seiring dengan peningkatan persen tanah tras.

Namun, pada benda uji dengan komposisi 90 : 10 yang terdiri dari $90 \%$ semen dan $10 \%$ tanah tras terjadi penurunan nilai kuat tekan padahal persen semennya meningkat. Hal ini dikarenakan pengadukan dan pemadatan yang kurang sempurna. Pemadatan yang kurang sempurna mengakibatkan adanya rongga udara di antara agregat yang mengurangi tingkat kepadatan beton. Selain itu, pengadukan yang kurang baik juga mengakibatkan terperangkapnya air di antara adukan beton. Ketika memasuki masa pengerasan, air akan menguap dan menyisakan rongga pada beton. Rongga-ronga pada beton menjadikannya rapuh sehingga menurunkan nilai kuat tekan [13].

Hasil kuat tekan kesepuluh benda uji memenuhi baku mutu kuat tekan yaitu sebesar $10 \mathrm{ton} / \mathrm{m}^{2}$ atau setara dengan 1 $\mathrm{kg} / \mathrm{cm}^{2}$. Setelah diperoleh nilai kuat tekan dari masing-masing benda uji, maka selanjutnya ditentukan komposisi binder yang digunakan untuk penelitian tahap II. Komposisi binder yang dipilih sebisa mungkin memiliki persentase semen yang rendah untuk menekan konsumsi semen. Namun, pemilihan komposisi tetap harus memperhatikan ketersediaan kapur atau kalsium hidroksida yang dibutuhkan untuk melangsungkan reaksi pozzolanic.

Berdasarkan hasil uji kuat tekan, benda uji dengan komposisi semen : tras $=10 \%: 90 \%$ telah memenuhi baku mutu nilai kuat tekan. Namun berdasarkan perhitungan secara stoikiometri, dengan semen sebesar $10 \%$ tidak tersedia $\mathrm{Ca}(\mathrm{OH})_{2}$ yang cukup untuk melangsungkan reaksi pozzolanic pada $90 \%$ tanah tras sisanya. $\mathrm{Ca}(\mathrm{OH})_{2}$ yang dibutuhkan tanah tras yaitu sebesar 153,18 gram, sedangkan $\mathrm{Ca}(\mathrm{OH})_{2}$ yang tersedia dari reaksi hidrasi semen hanya sebesar 50,42 gram. Reaksi pembentukan dan pemakaian $\mathrm{Ca}(\mathrm{OH})_{2}$ adalah [11] :

$\mathrm{CaO}+\mathrm{H}_{2} \mathrm{O} \rightarrow \mathrm{Ca}(\mathrm{OH})_{2} \quad$ (Reaksi hidrasi) $\mathrm{SiO}_{2}+\mathrm{Ca}(\mathrm{OH})_{2} \rightarrow \mathrm{CaO} \cdot \mathrm{SiO}_{2} \cdot \mathrm{H}_{2}$ (Reaksi pozzolanic)

Kebutuhan $\mathrm{Ca}(\mathrm{OH})_{2}$ untuk reaksi pozzolanic terpenuhi pada komposisi semen : tanah tras $=40 \%: 60 \%$. Dengan komposisi tersebut, dari reaksi hidrasi semen dihasilkan 118,42 gram $\mathrm{Ca}(\mathrm{OH})_{2}$. Sedangkan kebutuhan untuk reaksi pozzolanic hanya sebesar 102,12 gram. Ketersediaan kapur yang cukup pada komposisi ini memungkinkan terjadinya reaksi hidrasi dan pozzolanic secara sempurna. Dengan demikian, komposisi terbaik antara semen dan tanah tras yang selanjutnya digunakan untuk penelitian tahap II yaitu 40:60.

\section{Uji Konsistensi Normal Benda Uji Tahap II}

Hasil uji konsistensi normal tahap II dapat dilihat pada Tabel 4. Berdasarkan tabel tersebut dapat dilihat bahwa peningkatan persen tailing yang digunakan juga meningkatkan kebutuhan air dalam pembuatan benda uji. Hal ini dikarenakan bijih emas yang diolah pada penambangan emas rakyat Kulon Progo banyak berasal dari batuan andesit. Batuan andesit terdiri dari unsur-unsur kimia seperti silikat, aluminium, besi, kalsium, magnesium, natrium, kalium, tembaga, mangan, fosfor, sulfur, klor, nikel, barium, seng, dan air dengan komponen utama penyusunnya adalah silikat [16]. Silikat reaktif akan bereaksi dengan air sehingga menambah kebutuhan air pada adonan mortar. Dengan demikian, semakin

Tabel 4.

Kebutuhan Air Benda Uji Tahap II

\begin{tabular}{cc}
\hline \hline Binder : Tailing & Volume Air $(\mathrm{mL})$ \\
\hline $50: 50$ & 79 \\
$40: 60$ & 80 \\
$30: 70$ & 80 \\
$20: 80$ & 81 \\
$10: 90$ & 82 \\
$100: 0$ & 83 \\
\hline \hline
\end{tabular}


tinggi persen tailing maka volume air yang dibutuhkan juga semakin besar.

\section{E. Uji Kuat Tekan Benda Uji Tahap II}

Nilai kuat tekan masing-masing benda uji dapat dilihat pada Tabel 5. Grafik 2 menunjukkan hubungan nilai kuat tekan dengan persen binder dan tailing yang digunakan pada benda uji tahap II. Berdasarkan grafik tersebut dapat dilihat bahwa peningkatan persen semen dan tanah tras sebagai binder menghasilkan peningkatan pada nilai kuat tekan. Hal ini dikarenakan semakin banyak binder yang digunakan, maka partikel dalam benda uji akan terikat semakin kuat sehingga meningkatkan nilai kuat tekannya. Semen dan tanah tras mengandung komponen kalsium, silikat dan aluminat yang berperan penting dalam meningkatkan kuat tekan produk hasil $\mathrm{S} / \mathrm{S}$.

Keduanya akan membentuk kalsium silikat dan aluminat hidrat melalui proses hidrasi dan pozzolanic. Butiran silikat yang halus juga berfungsi sebagai bahan pengisi di antara rongga-rongga benda uji sehingga menjadi lebih padat. Kalsium berfungsi untuk proses perekatan atau pengikatan melalui proses hidrasi pada semen maupun melalui reaksi

Tabel 5.

Nilai Kuat Tekan Benda Uji Tahap II

\begin{tabular}{cc}
\hline \hline Binder : Tailing & Nilai Kuat Tekan $(\mathrm{kg} / \mathrm{cm} 2)$ \\
\hline $10: 90$ & 9.8 \\
$20: 80$ & 34 \\
$30: 70$ & 54.4 \\
$40: 60$ & 74.4 \\
$50: 50$ & 92.4 \\
$100: 0$ & 160.6 \\
\hline \hline
\end{tabular}

pozzolanic dengan tanah tras. Sedangkan aluminat berfungsi untuk mempercepat proses pengerasan [17]. Nilai kuat tekan seluruh benda uji tahap II memenuhi baku mutu kuat tekan.

\section{F. Uji TCLP}

Pelaksanaan uji TCLP diawali dengan preliminary evaluation untuk menentukan larutan ekstraksi yang digunakan untuk melarutkan merkuri. Penentuan larutan ekstraksi didasarkan pada $\mathrm{pH}$ sampel setelah dilakukan proses preliminary evaluation. Apabila $\mathrm{pH}<5$, maka digunakan larutan ekstraksi 1 dengan $\mathrm{pH} 4,93$. Sedangkan apabila $\mathrm{pH}>$ 5 , maka digunakan larutan ekstraksi 2 dengan $\mathrm{pH} 2,88 . \mathrm{pH}$ kelima sampel setelah preliminary evaluation memiliki $\mathrm{pH}>5$ sehingga digunakan larutan ekstraksi 2.

Larutan ekstraksi 2 mengandung asam asetat glasial yang dapat melarutkan merkuri dalam bentuk presipitat $\mathrm{HgO} . \mathrm{pH}$ larutan yang asam memungkinkan terlarutnya merkuri dengan membentuk senyawa $\mathrm{Hg}\left(\mathrm{CH}_{3} \mathrm{COO}\right)_{2}$ yang bersifat larut. Adapun reaksi yang terjadi selama proses ekstraksi adalah sebagai berikut :

$\mathrm{HgO} \downarrow+2 \mathrm{CH}_{3} \mathrm{COOH} \rightarrow \mathrm{Hg}\left(\mathrm{CH}_{3} \mathrm{COO}\right)_{2}$ (larut) $+\mathrm{H}_{2} \mathrm{O}$

Merkuri yang terlarut dalam bentuk $\mathrm{Hg}\left(\mathrm{CH}_{3} \mathrm{COO}\right)_{2}$ selanjutnya diuji konsentrasinya. Nilai TCLP dapat dilihat pada Tabel 6. Hasil uji TCLP benda uji dengan komposisi 50:50 dan 100:0 tidak terdeteksi sebab konsentrasi merkuri

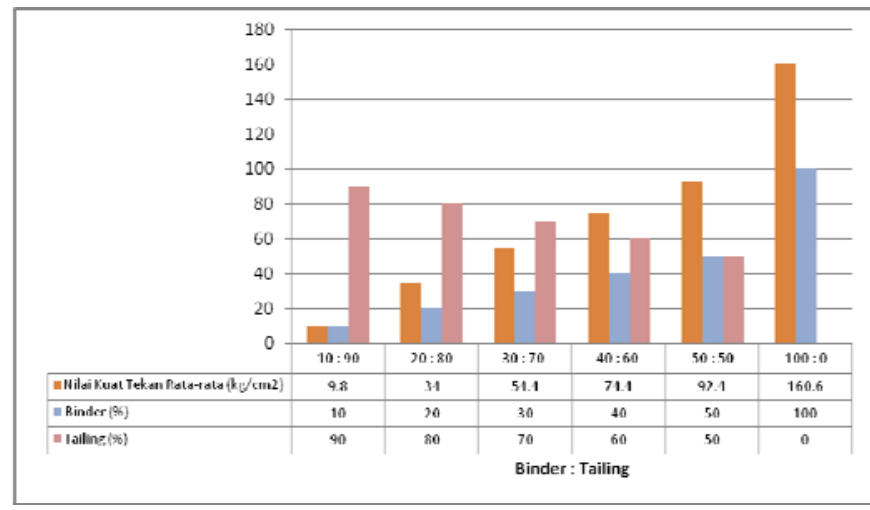

Grafik 2. Nilai Kuat Tekan Benda Uji Tahap II.

pada sampel lebih rendah dari batas konsentrasi terendah yang dapat dibaca (limit of detection) alat ukur. LOD dari alat ICPAES yang digunakan yaitu $0,21 \mathrm{mg} / \mathrm{L}$. Dengan demikian maka dapat dinyatakan bahwa konsentrasi merkuri pada benda uji dengan komposisi 50:50 dan 100:0 adalah kurang dari 0,21 $\mathrm{mg} / \mathrm{L}$.

Tabel 6 menunjukkan bahwa semakin tinggi persen binder maka nilai TCLP semakin rendah. Nilai TCLP untuk komposisi binder : tailing $=10: 90$ merupakan hasil estimasi sebab nilai TCLP dari hasil pengukuran dinilai menyimpang terlalu jauh dari rangkaian data lainnya sehingga ditetapkan sebagai outlier. Selanjutnya menggunakan kurva regresi diperoleh persamaan antara nilai kuat tekan (x) dengan hasil uji TCLP (y) sebagai berikut :

$$
y=-0,038 x+5,292
$$

Dengan menggunakan persamaan tersebut, estimasi nilai TCLP dari benda uji komposisi 10:90 yaitu sebesar 4,92 $\mathrm{mg} / \mathrm{L}$.

Peningkatan persen binder pada benda uji memberikan penurunan terhadap hasil uji TCLP. Semakin rendah hasil uji TCLP, maka konsentrasi merkuri yang berhasil terlindikan juga semakin rendah. Hal ini dikarenakan semakin banyak merkuri yang terikat dalam matriks semen dan tanah tras. Merkuri terikat secara kimia ketika bereaksi dengan senyawa basa dan karbonat yang terdapat dalam semen [18]. Ketika merkuri bereaksi dengan larutan basa akan terbentuk kristal $\mathrm{HgO}$ yang tidak larut meski dilakukan penambahan larutan basa secara berlebih [19]. Proses pembentukan kristal HgO dapat dilihat melalui reaksi berikut :

\begin{tabular}{|c|c|c|c|}
\hline Proses & $\begin{array}{l}\mathrm{Hg}^{2+}+\mathrm{OH}^{-} \\
\text {hidrasi sen }\end{array}$ & $\begin{array}{l}\downarrow+\mathrm{H}_{2} \mathrm{O} \\
\text { ghasilkan } \\
6 . \\
\text { TCLP }\end{array}$ & $\mathrm{Ca}(\mathrm{OH})_{2} \quad$ yang \\
\hline & Binder : Tailing & Nilai & TCLP (mg/L) \\
\hline & $10: 90$ & & $4,92^{*}$ \\
\hline & $20: 80$ & & 4,61 \\
\hline & $30: 70$ & & 4,09 \\
\hline & $40: 60$ & & 1,83 \\
\hline & $50: 50$ & $\mathrm{TD}^{* *}$ (kada & a $\mathrm{Hg}<0,21 \mathrm{mg} / \mathrm{L})$ \\
\hline & $100: 0$ & $\mathrm{TD}^{* *}$ (kada & or $\mathrm{Hg}<0,21 \mathrm{mg} / \mathrm{L})$ \\
\hline
\end{tabular}


merupakan basa kuat. $\mathrm{Ca}(\mathrm{OH})_{2}$ yang terbentuk selanjutnya bereaksi dengan $\mathrm{Hg}^{2+}$ dan membentuk kristal $\mathrm{HgO}$ sesuai reaksi di atas.

Kristal $\mathrm{HgO}$ yang secara kimia lebih stabil dibandingkan $\mathrm{Hg}^{2+}$ selanjutnya diikat secara fisik dalam matriks kalsium silikat hidrat dan kalsium aluminat hidrat dari proses hidrasi semen dan reaksi pozzolanic tanah tras. Merkuri dalam bentuk presipitat hidroksida dan garam karbonat tersebut terikat dalam struktur kristalin yang tidak larut [20].

Grafik 3 menunjukkan hasil uji TCLP dan nilai kuat tekan untuk tiap-tiap benda uji. Semakin tinggi nilai kuat tekan, maka hasil uji TCLP semakin rendah. Hal ini menunjukkan bahwa semakin tinggi kekuatan beton atau benda uji, maka merkuri juga terikat semakin kuat dalam struktur kristal yang

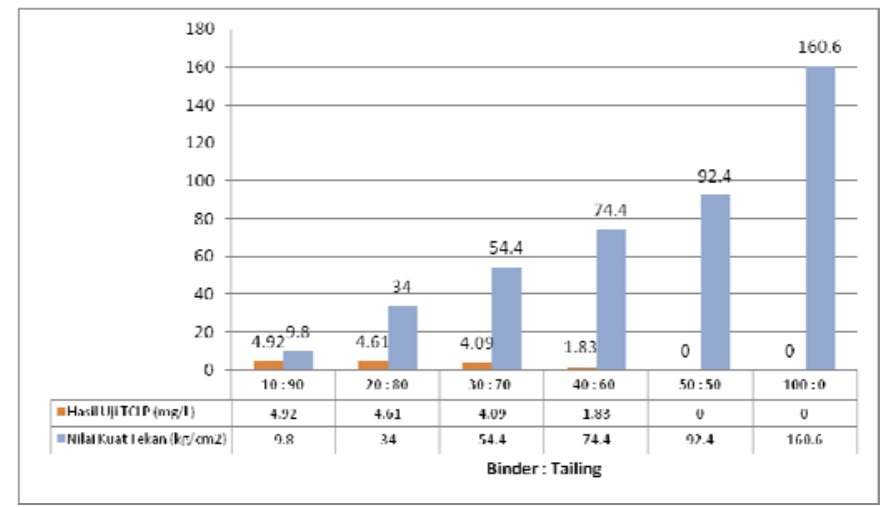

Grafik 3. Hasil Uji TCLP dan Nilai Kuat Tekan Benda Uji Tahap II.

dibentuk senyawa hidrat hasil reaksi hidrasi dan pozzolanic. Hal tersebut menjadikan tingkat kelarutan merkuri semakin rendah.

Berdasarkan baku mutu TCLP menurut Lampiran IV PP No 101 tahun 2014 yaitu sebesar $0,05 \mathrm{mg} / \mathrm{L}$, hanya benda uji dengan komposisi 50:50 yang memenuhi baku mutu. Dengan demikian ditetapkan komposisi terbaik antara binder dan tailing yang dapat digunakan dalam aplikasi solidifikasi/stabilisasi tailing tambang emas rakyat di Kulon Progo adalah 50:50.

\section{KESIMPULAN DAN SARAN}

Berdasarkan penelitian yang telah dilakukan, maka diperoleh hasil sebagai berikut :

1) Komposisi optimum antara semen Portland dan tanah tras adalah 40:60 dengan nilai kuat tekan sebesar 260,00 $\mathrm{kg} / \mathrm{cm}^{2}$.

2) Komposisi optimum antara campuran binder (semen dan tanah tras) dengan tailing adalah 50:50 dengan nilai kuat tekan $92,40 \mathrm{~kg} / \mathrm{cm}^{2}$ dan hasil uji TCLP $<0,21 \mathrm{mg} / \mathrm{L}$.

Saran untuk penelitian selanjutnya yaitu sebaiknya dalam pelaksanaan pengujian konsentrasi merkuri menggunakan metode dengan range limit of detection (LOD) yang lebih besar. Dengan demikian, sampel dengan konsentrasi merkuri yang sangat rendah ataupun sangat tinggi tetap dapat terukur.

\section{UCAPAN TERIMA KASIH}

Penulis mengucapkan terima kasih kepada Bapak Ranno
Marlany Rachman yang telah memberikan dukungan finansial untuk penelitian ini. Penulis juga mengucapkan terima kasih kepada Elok Dian Karisma Pagri Anisa, Ihsan Aulia Pamayo, Wahyuni Dwi Susilowati dan Zofar Banunaek atas dukungan dan kerja samanya dalam pelaksanaan penelitian ini.

\section{DAFTAR PUSTAKA}

[1] Stwertka, A. 1998. Guide to The Elements. New York : Oxford University Press

[2] Warlina, L. 2004. Pencemaran Air, Sumber dan Penanggulangannya. Bogor : Program Pasca Sarjana IPB

[3] Herman, D. Z. 2006. Pertambangan Tanpa Izin (PETI) dan Kemungkinan Alih Status Menjadi Pertambangan Skala Kecil. Buletin Vol. 1, No. 2 Penyelidik Bumi Madya, Kelompok Kerja Konservasi, Pusat Sumber Daya Geologi

[4] UNEP. 2008. The Global Atmospheric Mercury Assesment : Sources, Emissions and Transport. Geneva : UNEP-Chemicals

[5] Barth, E.F. 1990. An Overview of the History, Present Status, and Future Direction of Solidification/Stabilization Technologies for Hazardous Waste Treatment. Journal of Hazardous Materials, 24:103109

[6] Weitzman, L. 1990. Factors for Selecting Appropiate Solidification/Stabilization Methods. Journal of Hazardous Materials, 24:157-168

[7] Paria, S. dan Yuet, P. K. 2006. Solidification/Stabilization of Organic and Inorganic Contaminants Using Portland Cement : A Literature Review. Environmental Reviews, Volume 14:217-255

[8] Tariq, A. dan Yanful, E. K. 2013. A Review of Binders Used in Cemneted paste tailings for Underground and Surface Disposal Practices. Journal of Environmental Management, 131:138-149

[9] Palar, H., Monintja, S., Turangan, A.E. dan Sarajar, A.N. 2013. Pengaruh Pencampuran Tras dan Kapur Pada Lempung Ekspansif Terhadap Nilai Daya Dukung. Jurnal Sipil Statik, 1, 6:390-399

[10] Ulanadhari, O.W. 2014. Sistem Informasi Geografis Inventarisasi Bahan Galian Mineral dan Batu Bara Di Kabupaten Kulon Progo Daerah Istimewa Yogyakarta Berbasis Web (Studi Kasus : Dinas Perindustrian Perdagangan dan Energi Sumber Daya Mineral Kabupaten Kulon Progo). Fakultas Teknik, Sains dan Matematika, UPN Veteran Yogyakarta

[11] Putra, D. 2006. Penambahan Abu Sekam pada Beton dalam Mengantisipasi Kerusakan Akibat Magnesium Sulfat pada Air Laut. Jurnal Ilmiah Teknik Sipil Vol. 10 No. 2

[12] Sulastri, S. dan Kristianingrum, S. 2010. Berbagai Macam Senyawa Silika : Sintesis, Karakterisasi dan Pemanfaatan. Prosiding Seminar Nasional Penelitian, Pendidikan dan Penerapan MIPA, Fakultas MIPA, Universitas Negeri Yogyakarta, 15 Mei 2010

[13] Mulyati, S., Dahlan, D. dan Adril, E. 2012. Pengaruh Persen Massa Hasil Pembakaran Serbuk Kayu dan Ampas Tebu pada Mortar terhadap Sifat Mekanik dan Sifat Fisisnya. Jurnal Ilmu Fisika Vol. 4 No. 1

[14] Budi, G.S., Cristanto, A. dan Setiawan, E. 2003. Pengaruh Fly Ash terhadap Sifat Pengembangan Tanah Ekspansif. Civil Engineering Dimension, Vol. 5 No.1:20-24

[15] Hatmoko, J.T. dan Lulie, Y. 2007. UCS Tanah Lempung Ekspansif yang Distabilisasi dengan Abu Ampas Tebu dan Kapur. Jurnal Teknik Sipil Vol. 8 No. 1:64-77

[16] Yuliandini, A. dan Putra, A. 2013. Pengaruh Formasi Batuan Terhadap Karakteristik Hidrokimia Lima Sumber Mata Air Panas di Daerah Sapan, Pinang Awan, Kecamatan Alam Pauah Duo, Kabupaten Solok Selatan. Jurnal Fisika Unand Vol. 2 No. 4

[17] Wiryasa, N.M.A dan Sudarsana, I.W. 2009. Pemanfaatan Lumpur Lapindo Sebagai Bahan Substitusi Semen dalam Pembuatan Bata Beton Pejal. Jurnal Ilmiah Teknik Sipil, 13, 1:39-46

[18] LaGrega, M.D., Buckingham, P.I. dan Evans, J.C. 1994. Hazardous Waste Management. Singapore : McGraw-Hill, Inc

[19] Sugiata. 2010. Identifikasi Kation Secara Basah. Jurusan Pendidikan Kimia, Fakultas Matematika Dan IPA, Universitas Pendidikan Ganesha Singaraja

[20] Trihadiningrum, Y. 2000. Pengelolaan Limbah Bahan Berbahaya dan Beracun. Jurusan Teknik Lingkungan, FTSP, ITS Surabaya 
JURNAL TEKNIK ITS Vol. 5, No. 2, (2016) ISSN: 2337-3539 (2301-9271 Print) 